\title{
Cloning, expression, and characterization of cadmium-induced metallothionein-2 from the earthworms Metaphire posthuma and Polypheretima elongata
}

\author{
Shih-Hsiung Liang ${ }^{\mathrm{a}, 1}$, Yu-Ping Jeng ${ }^{\mathrm{a}, 1}$, Yuh-Wen Chiu ${ }^{\mathrm{b}}$, Jiun-Hong Chen ${ }^{\mathrm{c}}$, Bao-Sen Shieh ${ }^{\mathrm{b}}$, \\ Chien-Yen Chen ${ }^{\mathrm{d}}$, Chien-Cheng Chen ${ }^{\mathrm{a}, *}$ \\ a Department of Biotechnology, National Kaohsiung Normal University, 62 Shenjhong Rd., Yanchao Township, Kaohsiung County 82444, Taiwan \\ b Department of Biomedical Science and Environmental Biology, Kaohsiung Medical University, 100 Shihchuan 1st Road, Kaohsiung 807, Taiwan \\ ' Department of Life Science, National Taiwan University, 1 Roosevelt Road, Sec. 4, Taipei 10617, Taiwan \\ d Department of Earth and Environmental Sciences, National Chung Cheng University, 168 University Road, Min-Hsiung, Chiayi 621, Taiwan
}

\section{A R T I C L E I N F O}

\section{Article history:}

Received 30 June 2008

Received in revised form 27 August 2008

Accepted 3 September 2008

Available online 17 September 2008

\section{Keywords:}

ABTS

Cadmium

DTNB

Earthworm

Free radical scavenging

Metal-binding capability

Metallothionin-2

Phylogenetic analysis

\begin{abstract}
A B S T R A C T
In this study we report the sequences of MT-2 cDNA from two species of Megascoleidae earthworms, Metaphire posthuma and Polypheretima elongata, by mRNA differential display after exposure of the organisms to cadmium. Complementary (c)DNA was verified as the MT-2 gene by the characteristics of its predicted translation product, namely a high cysteine content, conserved CXC motifs, and a molecular weight of around $8 \mathrm{kDa}$. Amino acid sequence alignment revealed a conserved TKCCG in the cloned MT-2 of both megascolecid earthworms instead of the corresponding conserved TQCCG found in lumbricid earthworms. The cDNAs corresponding to the two megascolecid MT-2 genes were expressed, and the MT-2 proteins were purified for biochemical characterization. The binding of $\mathrm{Cu}^{2+}$ exhibited monophasic kinetics and those of $\mathrm{Zn}^{2+}$ and $\mathrm{Cd}^{2+}$ biphasic kinetics. The proteins bound more tightly to $\mathrm{Cd}^{2+}$ than to $\mathrm{Zn}^{2+}$ and more tightly still to $\mathrm{Cu}^{2+}$. $\mathrm{Zn}-\mathrm{MT}$ and apo-MT were the most effective at scavenging free radicals, followed by Cd-MT. In conclusion, MT-2s from $M$. posthuma and $P$. elongata showed unique sequence features compared to those of lumbricid earthworms. These earthworms could be used to evaluate heavy-metal pollution in soil due to the inducible MT-2 by cadmium exposure.
\end{abstract}

(c) 2008 Elsevier Inc. All rights reserved.

\section{Introduction}

Environmental pollutants, such as toxic chemicals, hazardous wastes, and heavy-metal contamination, currently evoke public concern about ecotoxicology. In particular, evidence is accumulating that heavy metals play important roles in the etiology of various diseases due to their acute and chronic toxicities. Earthworms were found to survive in arsenic-, cadmium-, and copper-contaminated mine sites (Morgan and Morgan, 1998; Piearce et al., 2002) and therefore are widely exploited in evaluating terrestrial ecotoxicology by reflecting heavy-metal contamination of soils (Dai et al., 2004). By ingesting large volumes of soil, earthworms come into direct contact with heavy metals and concentrate them, mainly in the chloragogenous tissue around the alimentary canal (Stürzenbaum et al., 2001). The biological effects of heavy metals on earthworms have been studied using a variety of parameters (Sheppard et al., 1997; Reinecke et al., 2001). For instance, quantification of physiological, structural, and behavioral responses has quite commonly been used (Dai et al., 2004; Lukkari and Haimi, 2005). Moreover, heavy-metal exposure can cause

\footnotetext{
* Corresponding author. Tel.: +886 7 7172930; fax: +886 76051353.

E-mail address: cheng@nknu.edu.tw (C.-C. Chen).

1 These authors contributed equally to this work.
}

morphological changes in earthworm coelomocytes and chloragocytes (Svendsen and Weeks, 1996; Morgan et al., 2004). Recently, changes in the intracellular concentrations of mono-oxygenase cytochrome P4501 and glutathione-S-transferase have become increasingly important as biomarkers for evaluating the effects of heavy-metal contaminants on organisms (Lukkari et al., 2004).

Metallothioneins (MTs), heavy-metal-inducible proteins that confer heavy-metal tolerance to various organisms, involved principally in the homeostasis of essential metals like $\mathrm{Cu}$ and $\mathrm{Zn}$ but also nonessential metal detoxication such as $\mathrm{Ag}, \mathrm{Cd}$ and $\mathrm{Hg}$ (Costello et al., 2004; Amiard et al., 2006). In addition to their function as metal chelators, MTs act as free radical scavengers, and MT isoforms can regulate tissue-specific development (Chen et al., 2004).

MTs are a ubiquitous family of low-molecular-weight substances widely found in animals, higher plants, eukaryotic organisms, and some prokaryotes, which contain $25 \%-30 \%$ cysteine, but few aromatic or histidine residues. This high cysteine content is the predominant feature of MTs and is necessary for the coordination of metal ions through the thiolate cluster provided by Cys-X-Cys motifs, in which $\mathrm{X}$ can be any amino acid other than cysteine. The MT protein is dumbbell-shaped, and the polypeptide backbone is wrapped around the metal thiolate core, forming the scaffold for two domains, designated $\alpha$ and $\beta$, separated by a short linker region. Each of the 
two domains binds metals with different affinities (Park et al., 2007). Structural analysis of MT-2 of the earthworm Lumbricus rubellus by circular dichroism spectroscopy suggested stoichiometries of $\mathrm{Cd}_{3} \mathrm{Cys}_{9}$ and $\mathrm{Cd}_{4} \mathrm{Cys}_{11}$ for the $\alpha$ (N-terminus) and $\beta$ (C-terminus) domains, respectively, which is the reverse situation to that seen in mammalian MTs (Ngu et al., 2006).

Although the amino acid sequences of more than 50 invertebrate MT and MT-like proteins have already been determined, little is known about the biochemical properties of earthworm MTs. So far, only 5 MT genes of lumbricid earthworms have been cloned from Lumbricus castaneus, Eisenia fetida, L. rubellus, and L. terrestris (Gruber et al., 2000). Phylogenetic information inferred from the MT-2 protein sequences has been reported in several organisms (Valls et al., 2001; Knapen et al., 2005; Kim et al., 2008; Santovito et al., 2007). However, this is the first report the phylogenetic comparison using earthworms MT-2 sequences. Nowadays, bioinformatic data for a given earthworm species can be readily obtained by protein and molecular biological approaches. The acquisition of additional MT-2 sequences from different earthworms will help in understanding earthworm MT-2 and provide new and more-precise means of delineating genera and in establishing phylogenetic distances between species. Furthermore, given the advantages of the abundance and wide distribution of earthworms, levels of MT-2s in local earthworm species can serve as a biomarker for heavy-metal contamination of the soil in many countries.

In the present study, we cloned the MT-2 gene from the megascolecid earthworms Metaphire posthuma and Polypheretima elongata to dissect the gene architecture of earthworm MT-2 and compared these MT-2 sequences with those of published earthworm MT-2 sequences to carry out a phylogenetic analysis. Moreover, recombinant proteins were produced to study the biochemical properties of earthworm MT-2s by investigating their metal-binding and free radical-scavenging abilities.

\section{Materials and methods}

\subsection{Cloning of earthworm MT-2s using messenger ( $m)$ RNA differential display}

The clitellated earthworms, M. posthuma and P. elongata, collected from fields in southern Taiwan, were cultured for 24 or $72 \mathrm{~h}$ in a jar containing $300 \mathrm{~g}$ of dry soil from the collection site in which no cadmium contamination was detected by atomic absorption spectrophotometry. In a parallel experiment, earthworms were cultured for 24 or $72 \mathrm{~h}$ in the same soil preparation containing added $\mathrm{CdCl}_{2}$ at a concentration of $400 \mathrm{mg}$ of $\mathrm{Cd} \mathrm{kg}^{-1}$ dry soil. Total RNA was isolated from the posterior alimentary canal and surrounding tissue using the TRIzol-reagent (Invitrogen), and $1 \mu \mathrm{g}$ RNA was used in a $13 \mu \mathrm{L}$ reverse transcription reaction mixture containing $2.5 \mathrm{mM}$ deoxyribonucleotide triphosphate (dNTP) (Takara) and $1.5 \mu \mathrm{M}$ of the primer, MTB-w1 (Table 1), which was incubated at $65{ }^{\circ} \mathrm{C}$ for $5 \mathrm{~min}$, then on ice for $1 \mathrm{~min}$. Following the addition of $4 \mu \mathrm{L}$ of $5 \times$ first-strand reverse transcription buffer, $1 \mu \mathrm{L}$ of $0.1 \mathrm{M}$ dithiothreitol (DTT), $1 \mu \mathrm{L}$ (40 U) of RNase inhibitor, and $1 \mu \mathrm{L}$ (200 U) of Superscript III RT (Invitrogen), the reaction mixture was incubated at room temperature for $10 \mathrm{~min}, 55^{\circ} \mathrm{C}$ for $60 \mathrm{~min}$, and $75{ }^{\circ} \mathrm{C}$ for $15 \mathrm{~min}$; then $1 \mu \mathrm{L}(60 \mathrm{U}$ ) of RNase $\mathrm{H}$ was added, and the sample was incubated at $37^{\circ} \mathrm{C}$ for $20 \mathrm{~min}$. After completion of this first-strand complementary (c)DNA synthesis, the partial cDNA fragment was amplified by the polymerase chain reaction (PCR) using the anchored primer, MTB-w2, and degenerate primers designed from highly conserved amino acid motifs of the MT superfamily (Table 1 ).

Primer combinations $(2.5 \mu \mathrm{M}$ of each of the forward and reverse primers) were used in $25 \mu \mathrm{L}$ of an amplification mixture containing $0.5 \mu \mathrm{L}$ of ss-cDNA, $5 \mathrm{U}$ of r-Taq DNA polymerase (Takara), $150 \mathrm{pmol}$ of anchored primer, $50 \mathrm{pmol}$ of degenerate primers, and 4 pmol of dNTP.
After an initial denaturation for $5 \mathrm{~min}$ at $94{ }^{\circ} \mathrm{C}$, the mixture was incubated at $94{ }^{\circ} \mathrm{C}$ for $30 \mathrm{~s}, 42{ }^{\circ} \mathrm{C}$ for $1 \mathrm{~min}$, and $72{ }^{\circ} \mathrm{C}$ for $30 \mathrm{~s}$ for 30 cycles, followed by a final 5 -min extension at $72^{\circ} \mathrm{C}$. The amplified cDNA fragments were separated by gel electrophoresis on a $1 \%$ agarose gel, with the control and induced cDNA preparations running side by side. Bands differentially expressed in the induced condition were excised from the gel, and the PCR product was extracted using a gel extraction kit (Qiagen).

\subsection{TA cloning and $5^{\prime}-R A C E$}

The PCR product ( $150 \mathrm{ng}$ ) purified using a PCR clean kit (Qiagen) was ligated into the pGEM-T vector (Promega) using $1 \mu \mathrm{L}$ of T4 DNA ligase (3 $\mathrm{U}$ ) in a total reaction volume of $10 \mu \mathrm{L}$ containing $5 \mu \mathrm{L}$ of $2 \times$ Rapid Ligation Buffer (final concentration: $30 \mathrm{mM}$ Tris- $\mathrm{HCl}, 10 \mathrm{mM} \mathrm{MgCl}$, $10 \mathrm{mM}$ DTT, $2 \mathrm{mM}$ ATP, and 5\% polyethylene glycol), and the ligation mixture was used to transform competent Escherichia coli DH5 $\alpha$ cells, which were streaked on $50 \mathrm{\mu g} \mathrm{ml}^{-1}$ ampicillin LB (Luria-Bertani) plates containing 5-bromo-4-chloro-3-indolyl- $\beta$-D-galactopyranoside (X-gal) and isopropyl- $\beta$-D-thiogalactopyranoside (IPTG). White colonies were examined by PCR using the M13 forward and reverse primers. Insert-containing plasmids were isolated using a Qia DNA minikit (Qiagen) (Kimura, 1980) and sequenced on an ABI 37302XL DNA sequencer (Applied Biosystems). cDNA ( $5 \mu \mathrm{L})$ was polyC-tailed by the addition of a final concentration of $5 \mathrm{mM} \mathrm{dCTP}$ and $4 \mu \mathrm{L}$ of $5 \times$ terminal

Table 1

Oligonucleotide primers used

\begin{tabular}{|c|c|c|c|}
\hline Oligo name & Sequence $\left(5^{\prime} \rightarrow 3^{\prime}\right)^{\mathrm{a}}$ & Remarks $^{\mathrm{b}}$ & Reference \\
\hline MTB-w1 & $\begin{array}{l}\text { R:CGGAGATCTCCAAT } \\
\text { GTGATGGGAATTC }(T)_{17}\end{array}$ & cDNA & $\begin{array}{l}\text { (Gruber et al., } \\
2000)\end{array}$ \\
\hline MTB-w2 & $\begin{array}{l}\text { R:CGGAGATCTCCAAT } \\
\text { GTGATGGGAATTC }\end{array}$ & amplification & $\begin{array}{l}\text { (Gruber et al., } \\
2000 \text { ) }\end{array}$ \\
\hline MT-115 & F:TGCCCATGTGG & 3'-RACE; DP & $\begin{array}{l}\text { (Stürzenbaum } \\
\text { et al., 1998) }\end{array}$ \\
\hline MT-116 & F:TGCCCATGCGG & & $\begin{array}{l}\text { (Stürzenbaum } \\
\text { et al., 1998) }\end{array}$ \\
\hline MT-117 & F:CTGCAAGTGT & & $\begin{array}{l}\text { (Stürzenbaum } \\
\text { et al., 1998) }\end{array}$ \\
\hline MT-118 & F:CTGCAAGTGC & & $\begin{array}{l}\text { (Stürzenbaum } \\
\text { et al., 1998) }\end{array}$ \\
\hline TKC-1 & F:ACCAAGTGCTGTGGA & & \\
\hline TKC-2 & F:ACTAAGTGCTGTGGA & & \\
\hline TKC-3 & F:ACCAAATGCTGTGGA & & \\
\hline TKC-4 & ACTAAATGCTGTGGA & & \\
\hline TKC-5 & F:ACCAAGTGCTGTGGAAA & & \\
\hline TQC-1 & F:ACTCAGTGCTGTGGA & & \\
\hline TQC-2 & F:ACTCAATGCTGTGGA & & \\
\hline CGN-1 & $\begin{array}{l}\text { F:TGTGGAAA } \\
\text { TGCAGGCTGC }\end{array}$ & & \\
\hline CGN-2 & F:TGTGGAAATGCAAGCTGC & & \\
\hline GCK-1 & $\begin{array}{l}\text { F:GGATGCAAGAAG } \\
\text { GGGTGCTGTGGTGAC }\end{array}$ & & \\
\hline GCK-2 & $\begin{array}{l}\text { F:GGATGCAAGAAGG } \\
\text { GATGCTGTGGTGAC }\end{array}$ & & \\
\hline GCK-3 & $\begin{array}{l}\text { F:GGATGCAAGAAAG } \\
\text { GATGCTGTGGTGAC }\end{array}$ & & \\
\hline 5RACE F-1 & $\begin{array}{l}\text { F:GGTTGAGAACTCT } \\
\text { TCTAC }(G)_{17}\end{array}$ & 5'-RACE & \\
\hline 5RACE F-2 & F:GGTTGAGAACTCTTCTAC & & \\
\hline M.po5RACE-R & R:TTTACAGTCTGCACCGCA & & \\
\hline P.el 5RACE-R & R:TGGCATTTCCACATTTTGC & & \\
\hline M.po pGEX-F & $\begin{array}{l}\text { F:GCCGCGGATCCATG } \\
\text { TCTGACAATACC }\end{array}$ & $\begin{array}{l}\text { Primer for construction } \\
\text { of expression plasmid }\end{array}$ & \\
\hline M.po pGEX-R & $\begin{array}{l}\text { R:CCGCTCGAGCTACT } \\
\text { TGCATGATCCC }\end{array}$ & & \\
\hline P.el pGEX-F & $\begin{array}{l}\text { F:GCCGCGGATCCATG } \\
\text { TCTGACAATACC }\end{array}$ & & \\
\hline P.el pGEX-R & $\begin{array}{l}\text { R:CCGCTCGAGCTACT } \\
\text { TGCATGATCCC }\end{array}$ & & \\
\hline
\end{tabular}

\footnotetext{
a Restriction sites are underlined.
}

b DP indicates degenerate primer. 
deoxynucleotidyl transferase buffer (100 $\mathrm{mM}$ potassium cacodylate (pH 7.2), $2 \mathrm{mM} \mathrm{CoCl}_{2}$, and $0.2 \mathrm{mM} \mathrm{DTT}$ ) in a total volume of $20 \mu \mathrm{L}$, and the sample was incubated at $94^{\circ} \mathrm{C}$ for $3 \mathrm{~min}$, then placed on ice for $1 \mathrm{~min}$. Terminal deoxynucleotidyl transferase (Invitrogen) at a final concentration of $1 \mathrm{U} \mathrm{LL}^{-1}$ was added to the mixture, which was incubated at $37{ }^{\circ} \mathrm{C}$ for $30 \mathrm{~min}$. Tailing was stopped by heating the mixture at $70{ }^{\circ} \mathrm{C}$ for $5 \mathrm{~min}$. The PCR was carried out in a $25 \mu \mathrm{L}$ final volume containing r-Taq buffer (Takara) ( $2 \mathrm{mM}$ Tris- $\mathrm{HCl}(\mathrm{pH} 8.0)$, $2 \mathrm{mM} \mathrm{MgCl}_{2}, 10 \mathrm{mM} \mathrm{KCl}_{2}, 0.01 \mathrm{mM}$ ethylenediaminetetraacetic acid (EDTA), $0.1 \mathrm{mM}$ DTT, 0.05\% Tween-20, 0.05\% Nonidet P-40, and 5\% glycerol), $0.5 \mathrm{U}$ of r-Taq polymerase (TaKaRa), $10 \mathrm{mM}$ dNTP mixture, $5 \mu \mathrm{L}$ of template DNA, and $0.5 \mu \mathrm{M}$ primers (forward primer, 5RACE F; reverse primer, Mpo-5RACE $\mathrm{R}$ or Pel-5RACE $\mathrm{R}$ ) for 30 cycles (preheating at $95{ }^{\circ} \mathrm{C}$ for $5 \mathrm{~min}$, denaturation at $95{ }^{\circ} \mathrm{C}$ for $30 \mathrm{~s}$, annealing at $55{ }^{\circ} \mathrm{C}$ for $30 \mathrm{~s}$, and extension at $72{ }^{\circ} \mathrm{C}$ for $30 \mathrm{~s}$ ), followed by a final $7 \mathrm{~min}$ extension at $72{ }^{\circ} \mathrm{C}$.

\subsection{Expression and purification of recombinant earthworm MT-2}

Using each pGEM-T MT-2 as a template, DNA was amplified by PCR with a pair of specific primers for the coding sequence of earthworm MT-2 (Table 1). The PCR products were digested with XhoI and BamHI and ligated into the pGEX-6p-3 expression vector (GE Healthcare). The recombinant earthworm MT-2 proteins were then expressed and purified. Briefly, the protease-deficient strain, E. coli BL-21 (GE Healthcare), was transformed with these constructed plasmids, and the transformed $E$. coli was grown in LB broth containing $100 \mu \mathrm{g} \mathrm{ml}^{-1}$ of ampicillin at $37{ }^{\circ} \mathrm{C}$. An overnight culture was diluted 100 -fold in fresh LB broth containing $50 \mu \mathrm{g} \mathrm{ml}^{-1}$ of ampicillin, and MT-2 protein production was induced by the addition of $1 \mathrm{mM}$ IPTG when the growing cells had attained an optical density of 0.5 at $600 \mathrm{~nm}$. Cells harvested from $1 \mathrm{~L}$ of culture were suspended in $30 \mathrm{ml}$ of cell lysis buffer [50 mM Tris- $\mathrm{HCl}$ (pH 8.5), $10 \mathrm{mM}$ EDTA, 5 mM DTT, and $1 \mathrm{mM}$ phenylmethanesulfonylfluoride], and the sample was sonicated. Soluble proteins were separated from cell debris by centrifugation at $15,000 \mathrm{~g}$ for $30 \mathrm{~min}$ at $4{ }^{\circ} \mathrm{C}$, then the supernatant was filtered on a $0.22 \mu \mathrm{m}$ filter (Millipore) and loaded onto a glutathione-Sepharose 4FF affinity column (GE Healthcare); then bound proteins were eluted using $10 \mathrm{mM}$ glutathione and subjected to a Superdex ${ }^{\mathrm{TM}} 75$ column (GE Healthcare). The collected GST-MT fusion proteins were cleaved with PreScission Protease in digestion buffer containing $50 \mathrm{mM}$ Tris$\mathrm{HCl}$ (pH 7.5), $150 \mathrm{mM} \mathrm{NaCl}, 1 \mathrm{mM}$ EDTA, and 1 mM DTT. After cleavage, samples were heated to $80{ }^{\circ} \mathrm{C}$ for $15 \mathrm{~min}$ and then centrifuged at $15,000 \mathrm{~g}$ for $10 \mathrm{~min}$ to pelletize the heat-labile proteins. The purified recombinant MT-2 was dissolved in $1 \times$ SDS sample buffer $(70 \mathrm{mM}$ Tris-HCl, 33 mM NaCl, 1 mM Na 2 EDTA, 2\% SDS, 40 mM DTT, 0.01\% bromophenol blue, and 10\% glycerol) and applied to $15 \%$ sodium dodecylsulfate polyacrylamide gel electrophoresis (SDS-PAGE) to monitor the protein purity.

\subsection{Phylogenetic analysis}

Phylogenetic reconstructions were performed using genetic distances, and neighbor-joining (NJ) and maximum parsimony (MP) analyses implemented in MEGA 4 (Molecular Evolutionary Genetics Analysis Program 4) (Kumar et al., 2007). Pair-wise evolutionary distances between haplotypes were calculated using Kimura's 2parameter (K2P) model (Saitou and Nei, 1987) and used to produce an NJ phylogenetic tree (Felsenstein, 1985) with MEGA4. Bootstrap values, indicating the robustness of the internal nodes of the $\mathrm{NJ}$ trees, were set at 1000 replications (Dolderer et al., 2007).

\subsection{Reactivity of metal-bound MT-2 with DTNB}

Reduced apo-MT was prepared by incubating $30 \mu \mathrm{M}$ purified recombinant MT-2 with $10 \mathrm{mM}$ DTT in DTNB buffer [ $10 \mathrm{mM}$ Tris-HCl
(pH 7.4) and $100 \mathrm{mM} \mathrm{KCl]}$ at $4{ }^{\circ} \mathrm{C}$ for $3 \mathrm{~h}$. Excess DTT was removed by dialysis twice against the same buffer without DTT, which had been degassed by sonication for $30 \mathrm{~min}$ in a biochemical oxygen demand bottle (Wheaton). To produce zinc (II)-MT, 7 molar equivalents of $\mathrm{ZnCl}_{2}$ were added to $30 \mu \mathrm{M}$ reduced apo-MT, and the mixture was incubated at $25{ }^{\circ} \mathrm{C}$ for $1 \mathrm{~h}$ (Jiang et al., 2000). Copper- $\left(\mathrm{CuCl}_{2}\right)$ and cadmium $\left(\mathrm{CdCl}_{2}\right)$-titrated MT-2s were prepared by the same procedure. The thiol reactivity of earthworm metal-MT was assayed using 5-5'dithiobis(2-nitrobenzoic) acid (DTNB) (Sigma) as described previously (Toriumi et al., 2005). In brief, MT-2 was dialyzed against the DTNB buffer, and the protein concentration was measured spectrophotometrically at $220 \mathrm{~nm}$ using $\varepsilon_{220}=117,680 \mathrm{M}^{-1} \mathrm{~cm}^{-1}$, then a mixture of $10 \mu \mathrm{M}$ DTNB and $10 \mu \mathrm{M}$ MT-2 was incubated at $25{ }^{\circ} \mathrm{C}$ for $60 \mathrm{~min}$. The free sulphydryl groups of MT- 2 were determined by the amount of 5-thio-2-nitrobenzoate, which were measured by optical absorption measurements at $412 \mathrm{~nm}$.

\subsection{2,2'-Azinobis-(3-ethylbenzothiazoline-6-sulfonic acid) (ABTS) radical assay}

The ABTS decolorization assay was performed as described previously (Dolderer et al., 2007). The ABTS radical cation was produced by mixing 2 volumes of $7 \mathrm{mM}$ ABTS in $10 \mathrm{mM}$ Tris- $\mathrm{HCl}$ (pH 7.4), $100 \mathrm{mM} \mathrm{KCl}$ (ABTS buffer) with 1 volume of $2.45 \mathrm{mM}$ potassium persulfate (Sigma) in ABTS buffer and incubating the mixture in the dark at room temperature for 12-16 h. Heavy-metalreconstituted MT-2s (Zn-MT, Cd-MT, and Cu-MT) were prepared using the procedure described in Section 2.5. The absorbance of the ABTS radical cation was adjusted to an $\mathrm{OD}_{734}$ of 0.7 by adding ABTS buffer, then $1 \mathrm{ml}$ of the ABTS cation solution was mixed with a final concentration of $3 \mu \mathrm{M}$ metal ion-titrated MT-2 in a cuvette with a 1$\mathrm{cm}$ path length, and the absorption was measured at $734 \mathrm{~nm}$ for $10 \mathrm{~min}$.

\section{Results}

\subsection{Cloning and sequence analysis of earthworm metallothionein-2}

The earthworms $M$. posthuma and P. elongata were collected from non-Cd-contaminated fields and cultured in soil with $\mathrm{CdCl}_{2}$ for 24 or $72 \mathrm{~h}$ to induce MT expression; then total RNA was isolated and used to generate cDNA with the primer MTB-w1. MTB-w2 and the degenerate primers were then used to amplify partial MT cDNA fragments (Table 1); the degenerate primers were designed from the amino acid sequence motifs that are highly conserved in comparison with MT-2 of the earthworm Eisenia foetida (Gruber et al., 2000). Although the earthworms were treated with $\mathrm{CdCl}_{2}$ for up to $72 \mathrm{~h}$ to ensure MT induction, the results (Fig. 1) showed that they responded to cadmium treatment within $24 \mathrm{~h}$, with no further increase with longer exposure. In $M$. posthuma, only the degenerate primers, TQC- 1 and TQC-2, resulted in two significant amplicons of 605 and $531 \mathrm{bp}$, respectively (Fig. 1A), suggesting that only these two primers were well annealed to the cDNA. To confirm that the amplified DNA bands under Cd treatment were MT-2 genes, they were extracted from the agarose gel and cloned into pGEM-T for DNA sequencing. The deduced amino acid sequence showed that only the 605-bp DNA fragment amplified by primer TQC-1 (from TQC to the C-terminus) shared high similarity with the same region of the reported MT sequences for lumbricid earthworms, whereas the 531-bp DNA fragment amplified by TQC-2 was homologous to NADH dehydrogenase subunit 5 (data not shown).

We thereafter employed 5'-RACE to obtain full-length cDNA using specific reverse primers based on the newly determined partial MT-2 sequences. In consequence, the full-length M. posthuma MT-2 654-bp cDNA consisted of a 258-bp coding sequence, a 55-bp 5' untranslated region (UTR), and a 341-bp 3' UTR (GenBank accession no. EU360938) (Fig. 2A). The glutamine residue in the normally conserved TQCCG in 
A
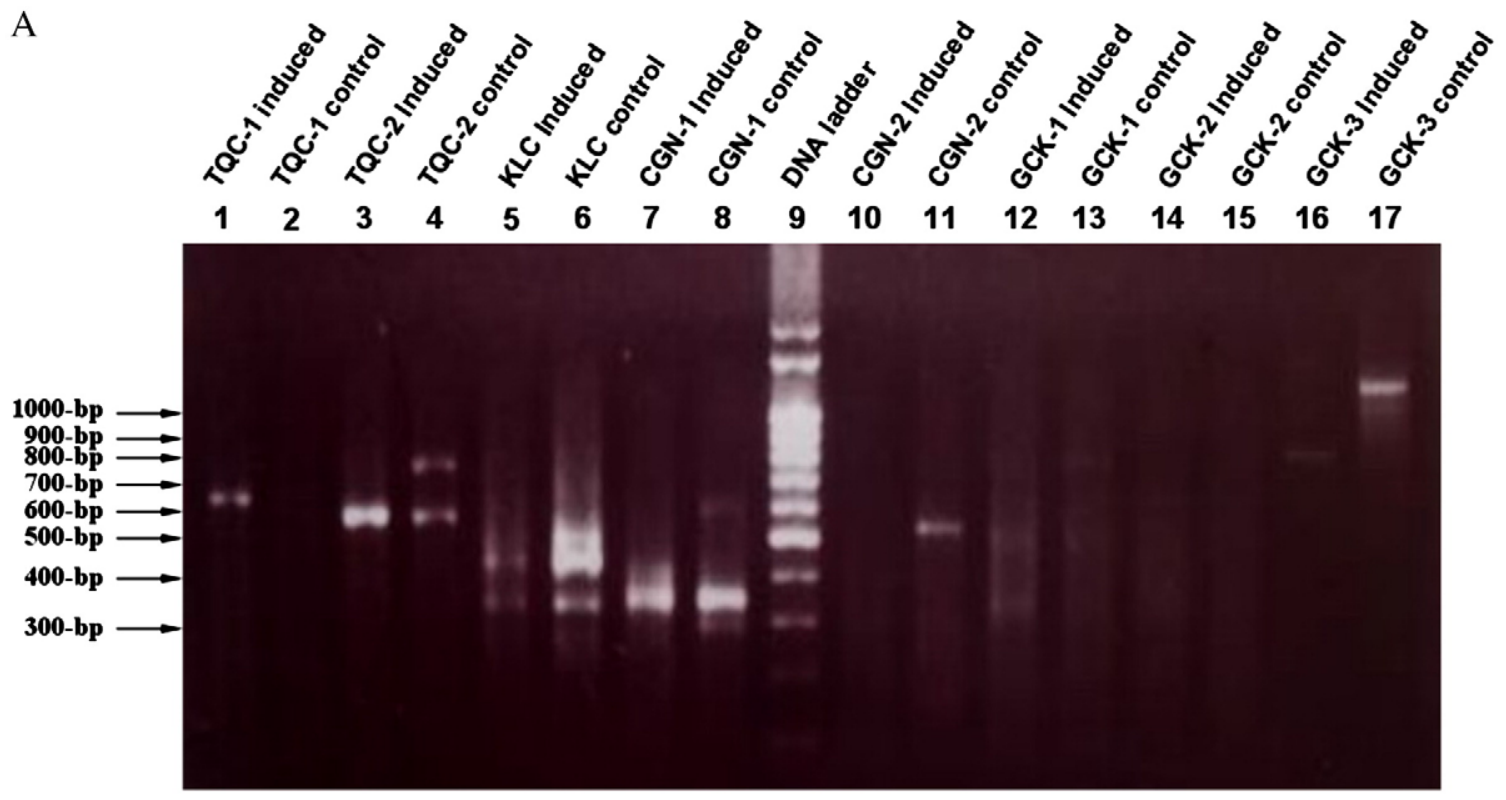

B
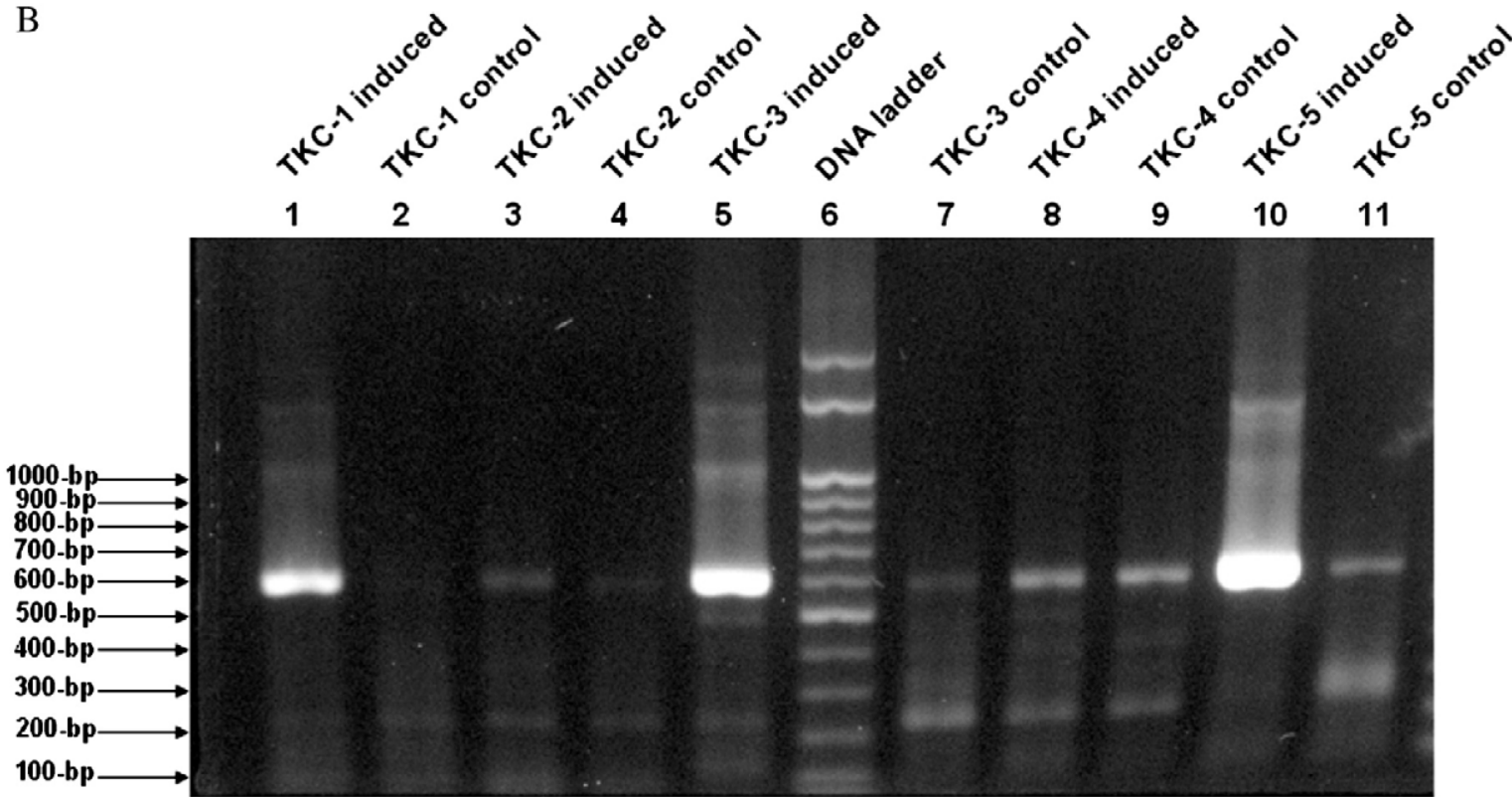

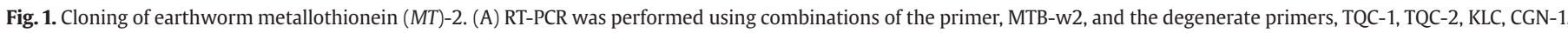

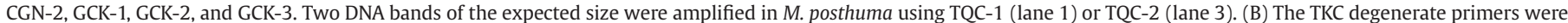
used to amplify P. elongata MT-2. Induced bands were seen when TKC-1 (lane 1), TKC-3 (lane 5), or TKC-5 (lane 10) was used.

lumbricid earthworms was replaced by lysine. Therefore the degenerate primers TKC-1, TKC-2, TKC-3, TKC-4, and TKC-5 designed from TKCCG were directly used to clone $P$. elongata MT-2, as both $M$. posthuma and $P$. elongata are members of the Megascolecidae. As a result, a DNA band was visualized using the primer combination of MTB-w1 with TKC-1, TKC-3, or TKC-5 (Fig. 1B), and identified as a part of MT-2 by DNA sequences analysis. After 5'-RACE, a 611-bp fulllength MT-2 cDNA was obtained consisting of a 243-bp coding region, a 55-bp 5' UTR, and a 313-bp 3' UTR (GenBank accession no. EU360939) (Fig. 2A).

The M. posthuma MT-2 gene encoded 83 amino acids, 22 of which were cysteines, while the $P$. elongata MT-2 gene encoded 80 amino acids, 20 of which were cysteines. The cysteine contents of the MT-2 proteins were calculated as $25 \%$ and $26.5 \%$ of the total amino acids in M. posthuma and P. elongata, respectively, consistent with the $23 \%$ $33 \%$ seen in other MTs (Hamer, 1986). Furthermore, the apparent molecular weights were estimated to be 8.47 and $8.06 \mathrm{kDa}$ for $M$. posthuma and $P$. elongata MT-2, respectively, and aromatic amino acids were absent from both proteins, both consistent with data for MTs in other organisms. Importantly, both MT-2 genes coded for most of the conserved cysteine residues and functional motifs, such as CXC and CC, that are essential for MT to chelate heavy metals. Amino acid sequence analysis revealed the duplicate CC motifs in both proteins, with four CXC motifs present in P. elongata and five in M. posthuma (Fig. 2B). Together, these features confirmed that these two cDNA sequences coded for $M$. posthuma and P. elongata MT-2.

\subsection{Phylogenetic analysis}

The two MT-2 sequences were compared to those of other earthworm MTs for evolutionary divergence analysis. Six nucleotide sequences containing 194 base pairs were analyzed and phylogenetic 
AATTAATTTCTGATTTTTGACCGAGTGAAAGTCGGCAAAAGCTTTGTGCGG AAAGATG TCT GAC AAT ACC AAG TGC $\begin{array}{llllllllll}M & \mathbf{S} & \mathbf{D} & \mathbf{N} & \mathbf{T} & \mathbf{K} & \mathbf{C}\end{array}$

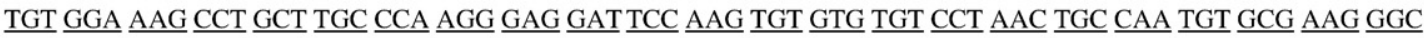
$\begin{array}{lllllllllllllllllllllll}\mathbf{C} & \mathbf{G} & \mathbf{K} & \mathbf{P} & \mathbf{A} & \mathbf{C} & \mathbf{P} & \mathbf{R} & \mathbf{E} & \mathbf{D} & \mathbf{S} & \mathbf{K} & \mathbf{C} & \mathbf{V} & \mathbf{C} & \mathbf{P} & \mathbf{N} & \mathbf{C} & \mathbf{Q} & \mathbf{C} & \mathbf{A} & \mathbf{K} & \mathbf{G}\end{array}$ $\underline{\text { GAG TGT }} \underline{\text { CTC }} \underline{\text { CCG }} \underline{\text { AAC }} \underline{\text { TGT }} \underline{\text { GAC }} \underline{\text { AAG }} \underline{\text { AAT TGT }} \underline{\text { TGT }} \underline{\text { GGA }} \underline{\text { ACA }} \underline{\text { GGG }} \underline{\text { TGT }} \underline{\text { GGT }} \underline{\text { TCA }} \underline{\text { GCA }} \underline{\text { AAA }} \underline{\text { TGT }} \underline{\text { GGC }} \underline{\text { AAT GCC }}$ $\begin{array}{lllllllllllllllllllllll}\mathbf{E} & \mathbf{C} & \mathbf{L} & \mathbf{P} & \mathbf{N} & \mathbf{C} & \mathbf{D} & \mathbf{K} & \mathbf{N} & \mathbf{C} & \mathbf{C} & \mathbf{G} & \mathbf{T} & \mathbf{G} & \mathbf{C} & \mathbf{G} & \mathbf{S} & \mathbf{A} & \mathbf{K} & \mathbf{C} & \mathbf{G} & \mathbf{N} & \mathbf{A}\end{array}$

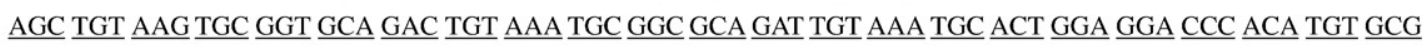
$\begin{array}{lllllllllllllllllllllll}\mathbf{S} & \mathbf{C} & \mathbf{K} & \mathbf{C} & \mathbf{G} & \mathbf{A} & \mathbf{D} & \mathbf{C} & \mathbf{K} & \mathbf{C} & \mathbf{G} & \mathbf{A} & \mathbf{D} & \mathbf{C} & \mathbf{K} & \mathbf{C} & \mathbf{T} & \mathbf{G} & \mathbf{G} & \mathbf{P} & \mathbf{T} & \mathbf{C} & \mathbf{A}\end{array}$

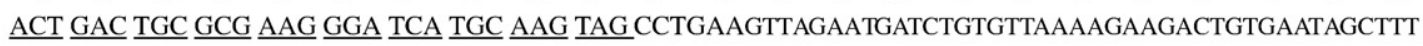
$\begin{array}{lllllllllll}\mathbf{T} & \mathbf{D} & \mathbf{C} & \mathbf{A} & \mathbf{K} & \mathbf{G} & \mathbf{S} & \mathbf{C} & \mathbf{K} & \text { stop }\end{array}$ ATTGAGCAGAAGAACGTGCATTTTGTTGGCTTTCGGCAGTTCTGCTTACTTACAATATGTTCAAGTTTTATGTGTTATTCCGACTCATTGTAGACT TGCTTAAATTGTTGAAAATGAGTTGATTATGGTTTCTACGTTGGATGTATTATTCATTGGGTCAGCATAGTATTTTAGAGAACAATCGATGGTTTCA AATTTAAATTATTCGTTCTGTTTTTTTTATTTTTTGCCGCTGTTGAAGAGAAATTTGCTTTCAAATTTGCTTTGCTTTAAAATAAATCGGCTTACAAA AGGAAAAAAAAAAAAAAAAAA

Polypheretima elongata

AAATTAAAGTCTGATTTTGAACAATTGAAAGTTGCGAAATCTTTGTGACGGAAAG $\underline{\text { TTG }} \underline{\text { TCT }} \underline{\text { GAC }} \underline{\text { AAT }} \underline{\text { ACC }} \underline{\text { AAA }} \underline{\text { TGC }}$ \begin{tabular}{llllllllll}
$M$ & $\mathbf{S}$ & $\mathbf{D}$ & $\mathbf{N}$ & $\mathbf{T}$ & $\mathbf{K}$ & $\mathbf{C}$ & & \\
\hline
\end{tabular}

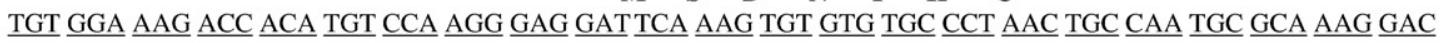
$\begin{array}{lllllllllllllllllllllll}\mathbf{C} & \mathbf{G} & \mathbf{K} & \mathbf{T} & \mathbf{T} & \mathbf{C} & \mathbf{P} & \mathbf{R} & \mathbf{E} & \mathbf{D} & \mathbf{S} & \mathbf{K} & \mathbf{C} & \mathbf{V} & \mathbf{C} & \mathbf{P} & \mathbf{N} & \mathbf{C} & \mathbf{Q} & \mathbf{C} & \mathbf{A} & \mathbf{K} & \mathbf{D}\end{array}$ $\underline{\text { AAT }} \underline{\text { TGT }} \underline{\text { CCC }} \underline{\text { CCA }} \underline{\text { AAC }} \underline{\text { TGC }} \underline{\text { GAC }} \underline{\text { AAG }} \underline{\text { AAC }} \underline{\text { TGT }} \underline{\text { TGT }} \underline{\text { GCA }} \underline{\text { TCA }} \underline{\text { GCA }} \underline{\text { GGG }} \underline{\text { TGT }} \underline{\text { GGT TCT }} \underline{\text { GCA }} \underline{\text { AAA }} \underline{\text { TGT }} \underline{\text { GGA }} \underline{\text { AAT }}$ $\begin{array}{lllllllllllllllllllllll}\mathbf{N} & \mathbf{C} & \mathbf{P} & \mathbf{P} & \mathbf{N} & \mathbf{C} & \mathbf{D} & \mathbf{K} & \mathbf{N} & \mathbf{C} & \mathbf{C} & \mathbf{A} & \mathbf{S} & \mathbf{A} & \mathbf{G} & \mathbf{C} & \mathbf{G} & \mathbf{S} & \mathbf{A} & \mathbf{K} & \mathbf{C} & \mathbf{G} & \mathbf{N}\end{array}$ $\underline{\text { GCC }} \underline{\text { AAC }} \underline{\text { TGC }} \underline{\text { AAA }} \underline{\text { TGC }} \underline{\text { GGT }} \underline{\text { GCG }} \underline{\text { GATTTC }} \underline{\text { AAG }} \underline{\text { TGC }} \underline{\text { ACT }} \underline{\text { GGA }} \underline{\text { GGC }} \underline{\text { CCC }} \underline{\text { GCA }} \underline{\text { TGT }} \underline{\text { GCA }} \underline{\text { ACT }} \underline{\text { GAG }} \underline{\text { TGC }} \underline{\text { GTG }} \underline{\text { AAG }}$ $\begin{array}{lllllllllllllllllllllll}\mathbf{A} & \mathbf{N} & \mathbf{C} & \mathbf{K} & \mathbf{C} & \mathbf{G} & \mathbf{A} & \mathbf{D} & \mathbf{C} & \mathbf{K} & \mathbf{C} & \mathbf{T} & \mathbf{G} & \mathbf{G} & \mathbf{P} & \mathbf{A} & \mathbf{C} & \mathbf{A} & \mathbf{T} & \mathbf{E} & \mathbf{C} & \mathbf{V} & \mathbf{K}\end{array}$

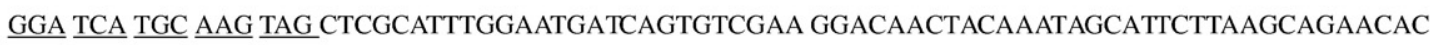
$\begin{array}{lllll}\text { G } & \mathbf{S} & \mathbf{C} & \mathrm{K} & \text { Stop }\end{array}$ GCATTTTGTCTTTTGGCATTTCCGCTTACAATGTACTGTGTTTAAGTTTTGTATCGTATTTCAACTCATTATTAGACTTGCTTGTATTGT TGAATATGAGTCAATTATGCTTGCGAAATTGGATGCAGCAGTGATGTGCTGACATTTGTTTAGAGGACGATTGATGATTTGAAATATA ATTTTTTTTGATTTTATGCTGTTGGAAAGAAATTTGCTTTAATATTTGTTTTGGTTTAAAATAAATCATTTTACAAAAAAAAAAAAAAA AAA

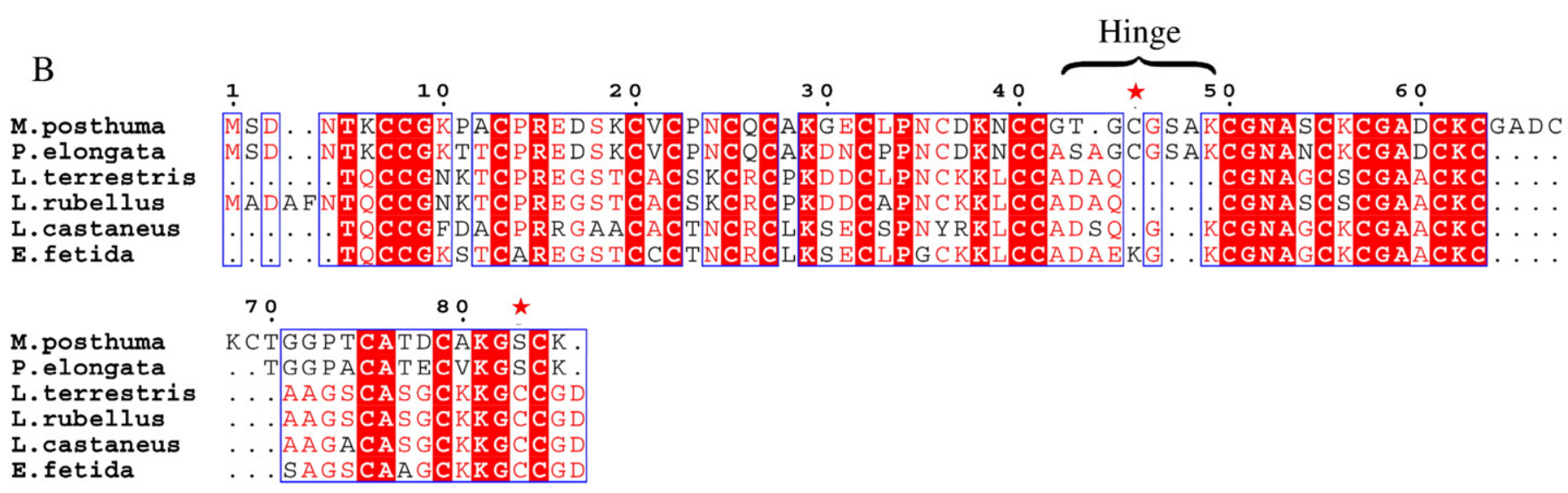

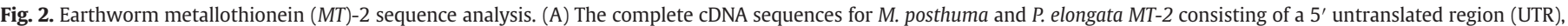

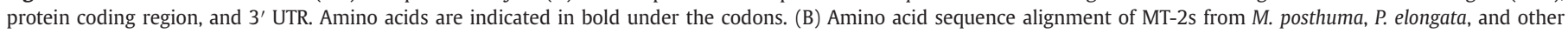
earthworms, showing high homology. The symbol $(\star)$ marks the additional cysteine residue within the hinge and the substitution of a cysteine residue by serine in $\beta$ domain.

relationships reconstructed using the NJ and MP tree methods. As shown in Fig. 3, the NJ and MP trees had the same topology, with the six sequences examined forming two major clusters. The three Lumbricus species ( $L$. rubellus, L. terrestris, and L. castaneus) were grouped in one clade, with E. fetida being closely related, but the lumbricid clade was distant from the megascolecid clade. The phylogenetic trees were also reconstructed using six amino acid sequences containing a total of 60 amino acids using the same methods. The phylogenic trees from amino acid data were not shown because of the same topology as nucleotide analysis. Together, these results imply that M. posthuma and $P$. elongata are closely related species, but clearly distant from lumbricid earthworms.

\subsection{Expression and purification of recombinant earthworm MT-2}

To examine the biochemical properties of earthworm MT-2, the recombinant proteins were overexpressed and purified from the protease-deficient E. coli BL21 strain. Two additional major protein bands with apparent molecular weights of about 26 and $34 \mathrm{kDa}$, respectively corresponding to glutathione $S$-transferase (GST) and 


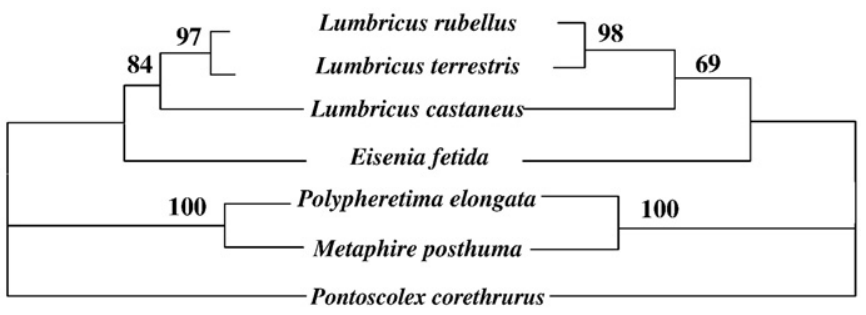

Neighbor -joining tree 0.05

Parsimony tree

10

Fig. 3. Phylogenetic relationships between earthworm metallothioneins (MTs) using nucleotide sequence. Neighbor-joining (NJ) tree and the most parsimonious tree $(\mathrm{CI}=0.893617)$ based on $194 \mathrm{bp}$ of MT nucleotide sequence for lumbricid and megascolecid earthworms. The numbers above the branches indicate the bootstrap scores based on 1000 replicates. Only values of $>50 \%$ are indicated. The figure was drawn using the program ESPript software (Gouet et al., 1999).

GST-MT, were seen on SDS-PAGE after IPTG induction compared to before IPTG addition (Fig. 4, lanes 2 and 3). We interpreted this result as certain $E$. coli proteases still being able to cleave GST-MT even though the protease-deficient E. coli strain was used. For protein purification, GST-MT and GST were trapped on glutathioneSepharose and co-eluted using $10 \mathrm{mM}$ glutathione, then were separated by gel filtration chromatography on Superdex ${ }^{\mathrm{TM}} 75$. Both GST-MTs were purified using this same procedure; the SDS-PAGE results for $M$. posthuma GST-MT are shown in Fig. 4 (lane 4). The purified GST-MT was then cleaved using PreScission Protease and heated to $80{ }^{\circ} \mathrm{C}$ for $15 \mathrm{~min}$ to precipitate all heat-labile proteins, leaving the thermo-stable recombinant MT-2. The purified recombinant $M$. posthuma and $P$. elongata MT-2 s were analyzed by SDSPAGE (Fig. 4, lanes 5 and 6, respectively). The estimated molecular masses of both recombinant MT-2s of around $20 \mathrm{kDa}$ were greater than the theoretical molecular mass of $8 \mathrm{kDa}$, even in the reducing buffer containing $40 \mathrm{mM}$ DTT.

\subsection{Reactivity of recombinant MT-2 with DTNB}

To investigate the metal-binding capability of earthworm MT-2, the DTNB reaction under pseudo-first-order conditions was initiated by adding $10 \mu \mathrm{M}$ DTNB to $10 \mu \mathrm{M}$ recombinant MT-2, which had been reconstituted with the metal ions $\mathrm{Cu}^{2+}, \mathrm{Zn}^{2+}$, or $\mathrm{Cd}^{2+}$ in Tris buffer ( $\mathrm{pH}$ 7.4). DTNB reacts in solution with free sulfhydryl groups, forming a thionitrobenzoate-protein complex and liberating a thionitrobenzoate anion, which is a vivid yellow color that absorbs maximally at $412 \mathrm{~nm}$. As shown in Fig. 5, the different metal-reconstituted MT-2s showed different reaction rates with DTNB in the order of $\mathrm{Zn}^{2+}<\mathrm{Cd}^{2+}<\mathrm{Cu}^{2+}$, suggesting that the affinities of recombinant earthworm MT-2 for metal ions were $\mathrm{Cu}^{2+}>\mathrm{Cd}^{2+}>\mathrm{Zn}^{2+}$.

The kinetics for the reaction of Zn-MT to DTNB was determined to be biphasic. The biphasic reaction is due to the two domains ( $\alpha$ and $\beta$ ) of MT-2 having different $\mathrm{Zn}^{2+}$-binding capabilities, resulting in distinct accessibilities of the sulfhydryl groups to DTNB (Toriumi et al., 2005; Park et al., 2007). In contrast, MT-Cd showed a relatively slow reaction, implying a higher metal-binding capability for $\mathrm{Cd}^{2+}$ than $\mathrm{Zn}^{2+}$. Moreover, Cd-MT from both earthworm species also exhibited biphasic reactions in a plot of $\ln \left(A_{\infty}-A_{t}\right)$ vs. time. Both MT-2s showed a much-slower monophasic reaction with $\mathrm{Cu}^{2+}$. Such a low rate constant indicates that earthworm MT-2s can tightly bind $\mathrm{Cu}^{2+}$, which has also been reported for MTs from other organisms (Toriumi et al., 2005; Park et al., 2007). M. posthuma MT-2 showed a slightly higher reactivity to DTNB than $P$. elongata MT-2, suggesting different metalbinding properties despite their close phylogenetic relationship (Fig. 3).

\subsection{Free radical-scavenging activity of recombinant earthworm MT-2}

Free radical-scavenging activity is one of the important properties of MTs, which acts as antioxidants to protect cells from oxidative damage (Atif et al., 2006; Reinecke et al., 2006). The extent of decolorization of the ABTS ${ }^{+}$radical cation is determined as a function of free radical-scavenging activity. As shown in Fig. 6A, the shape of the M. posthuma Cu-MT curve greatly differed from those of the apoMT, Zn-MT, and Cd-MT, in that dramatic decolorization was detected in the initial stage, but the absorbance then remained steady, suggesting inaccessibility of sulfhydryl groups in the steady phase. The free radical-scavenging activity of the three other curves decreased in the order of apo-MT $>\mathrm{Zn}-\mathrm{MT}>\mathrm{Cd}-\mathrm{MT}$. In agreement with the result for the weakness of Zn binding, as shown in Fig. 5 by the accessibility of the cysteines to DTNB, Zn-MT functions as a potent free radical scavenger due to the accessibility of sulfhydryl groups to ABTS. The results for $P$. elongata were very similar (Fig. 6B).

\section{Discussion}

Earthworms are soil-dwelling organisms frequently employed to test the relative health of soil ecosystems by detecting any biological disturbance. They show changes in bioviability, reproductive, developmental, neurological, and immunological molecular biomarkers in response to various stress conditions. Earthworm MT-2 was chosen as a useful biomarker to evaluate ecotoxicity because of its efficient induction by heavy metals in soil. To date, only few MT sequences for lumbricid earthworms have been completed and analyzed, and the restricted geographical distribution of lumbricid earthworms is also a drawback to their use as bio-indicators. We therefore cloned and sequenced MT-2 from the earthworms M. posthuma and P. elongata, which are widely distributed in Taiwan, East Asia, and South Asia, to examine if earthworm MT-2 might be used to assess the impact of heavy metal in more countries. MT-2 concentration in earthworm was determined with qPCR to evaluate the effect of cadmium exposure. Significant induction of MT-2 by application of cadmium chloride $80 \mathrm{ppm}$ during an incubation period (1-7-d) was detected, and the extent of MT-2 induction was 8.0-42.5-fold and 14.6-25.6-fold increases for $P$. elongata and $P$. posthuma, respectively (unpublished

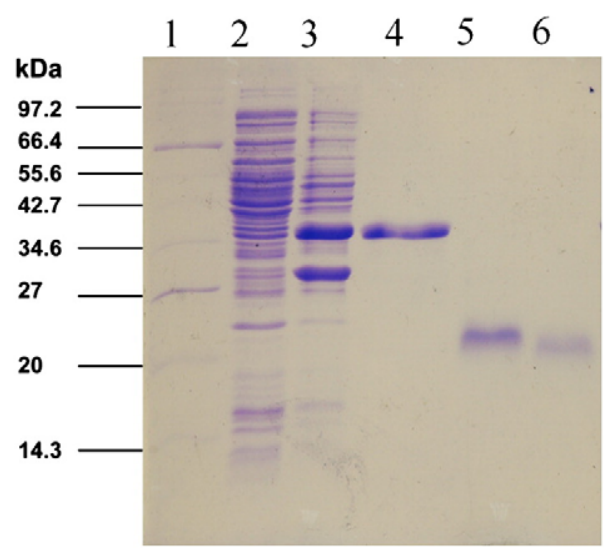

Fig. 4. Purification of recombinant earthworm metallothionein (MT)-2. Soluble proteins were extracted from $E$. coli cells transformed with a GST vector containing $M$. posthuma MT-2 or P. elongata MT-2. The protein samples were applied to SDS-PAGE. Lane 1, Marker proteins; lane 2, supernatant of the E. coli cell lysate before IPTG induction; lane 3, supernatant of the $E$. coli cell lysate after IPTG induction; lane 4, purified $M$. posthuma GST-MT by a glutathione-Sepharose $4 \mathrm{FF}$ affinity column followed by Superdex ${ }^{\mathrm{TM}} 75$ gel filtration chromatography; lane 5, purified recombinant $M$. posthuma MT-2 after PreScission Protease cleavage; lane 6, recombinant P. elongata MT-2 purified following the same procedures as recombinant M. posthuma MT-2. Labels on the left indicate the molecular masses of the marker proteins. 


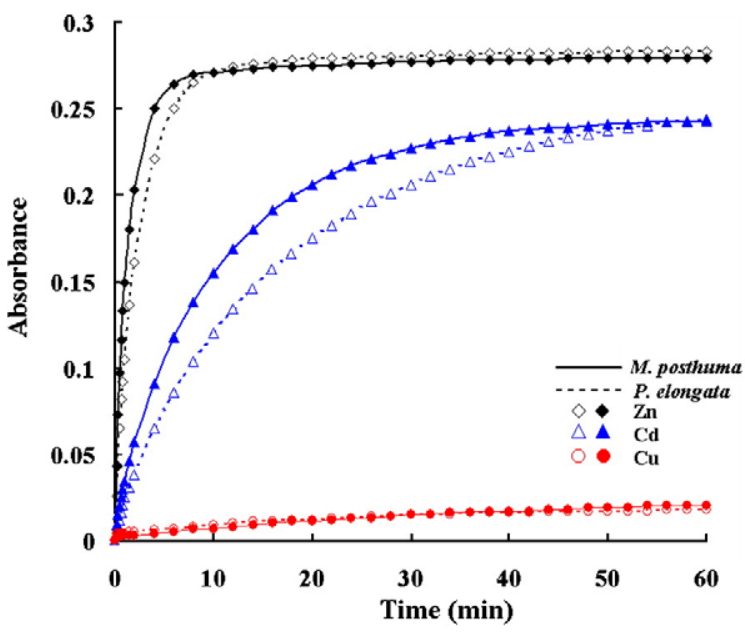

Fig. 5. Thiol reactivity of metal-reconstituted earthworm metallothionein (MT)-2 using DTNB. Earthworm MT-2 was incubated with $7 \mathrm{M}$ equivalents of metal ions $\left(\mathrm{Zn}^{2+}, \mathrm{Cd}^{2+}\right.$, and $\mathrm{Cu}^{2+}$ ), then $10 \mu \mathrm{M}$ of each metal-bound earthworm MT-2 was reacted with $10 \mu \mathrm{M}$ DTNB and the absorbance was measured spectrophotometrically at $412 \mathrm{~nm}$. Means of three replications were displayed for absorbance measurements at each recorded time point.

data). All tested earthworms were viable representing the cadmium tolerance $(80 \mathrm{ppm})$ for both earthworm species at least for 7-d.

The degenerate primers used in this study were designed from the known conserved amino acid motif, TQCCG, of MT-2 from E. foetida, a lumbricid earthworm. However, instead of TQCCG, we found a related TKCCG sequence in the megascolecid earthworms, $M$. posthuma and $P$. elongata. In addition to TKCCG, another conserved region, KGSCK, was situated at the C-terminus in these earthworm MT-2s. Based on the TKCCG sequence, we designed specific primers and succeeded in cloning full-length MT-2 from several other Taiwan earthworms, including of the Amynthas, Metaphire, and Polypheretima genera of the Megascolecidae and Pontoscolex of the Glossoscolecidae; this conserved region was also found in other members of the Megascolecidae (unpublished data).

Our data showed that the nucleotide sequence encoding TKCCG was relatively conserved compared to the corresponding sequences encoding TQCCG in lumbricid earthworm MTs (data not shown). This is consistent with the PCR result showing that the only degenerate primers able to amplify MT-2 cDNA were those obtained from TQCCG (Fig. 1A). Both the amino acid sequences and nucleotide sequences of the MTs can potentially be used for phylogenetic analyses (Knapen et al., 2005). The phylogenetic analysis showed that the sequences of lumbricid earthworms were grouped in a clade in which L. rubellus and $L$. terrestris are closely related taxa because of the high bootstrap value. The sequences of the two megascolecid earthworms, P. elongata and $M$. posthuma, formed a robust clade as a result of being in the same family.

Amino acid sequence alignment revealed the presence of a tandem repeat of GADCKC in the $\beta$ domain of $M$. posthuma, but not in other earthworms, in which a single GADCKC was seen. Intragenic tandem repeats in proteins have been proposed to generate functional variability. In particular, the CKC, seen in the tandem repeats, is a significantly conserved functional motif in MTs and is responsible for metal coordination (Verstrepen et al., 2005). M. posthuma MT-2, with an additional CKC, exhibited a slightly higher affinity than $P$. elongata for the metal ions $\mathrm{Cu}^{2+}, \mathrm{Cd}^{2+}$, and $\mathrm{Zn}^{2+}$. Moreover, both P. elongata and M. posthuma MT-2s contained an additional cysteine residue in the vicinity of the hinge compared to lumbricid earthworms, but a cysteine residue in the $\beta$ domain in lumbricid earthworms was replaced by serine (Fig. $2 \mathrm{~B}$ ).

M. posthuma and P. elongata have different soil depth niches: the former inhabits the mineral soil horizons (an endogenic species) and the latter typically lives on the soil surface (an epigenic species). Several soil properties of these niches $(\mathrm{pH}$, organic matter, inorganic salts, and heavy metals) can affect the survival of earthworms. Although M. posthuma and P. elongata are both exotic earthworms, they have already become common species in Taiwan. We therefore were interested in determining whether their MT-2s can sequester heavy metals more effectively and help in environmental adaptation. The analysis of the biochemical properties of recombinant earthworm MT-2 proteins enabled us to investigate whether the speciesspecificity of metal sequestration by MT-2 was relevant to environmental adaptation. In previous studies, metal-bound MT was purified from organisms pretreated with heavy metals (Atif et al., 2006) or overexpressed in bacteria grown in divalent ion-supplemented media (Toriumi et al., 2005). These preparations consisted of metal-bound MT, but may also have contained oxidized MT and metal-free MT, which would not give an accurate measurement in metal-binding assays. In contrast, our recombinant MT proteins were overproduced in E. coli in the absence of heavy metals, and the purified recombinant MTs were further entirely reduced by the addition of $10 \mathrm{mM}$ DTT, so we were able to test the metal-binding capability using a homogenous reduced form of MT.

MT is reported to migrate on SDS-PAGE at a position corresponding to a higher molecular mass than expected (Valls et al., 2001; Toriumi et al., 2005). Consistent with this, the recombinant earthworm MT-2s had apparent molecular weights exceeding $20 \mathrm{kDa}$ on SDS-PAGE, even when treated with DTT buffer (Fig. 4). Regarding the metal-binding capability, the two earthworm MT-2s preferentially sequestered metal ions in the order of $\mathrm{Cu}^{2+}>\mathrm{Cd}^{2+}>\mathrm{Zn}^{2+}$, as shown for MTs from other
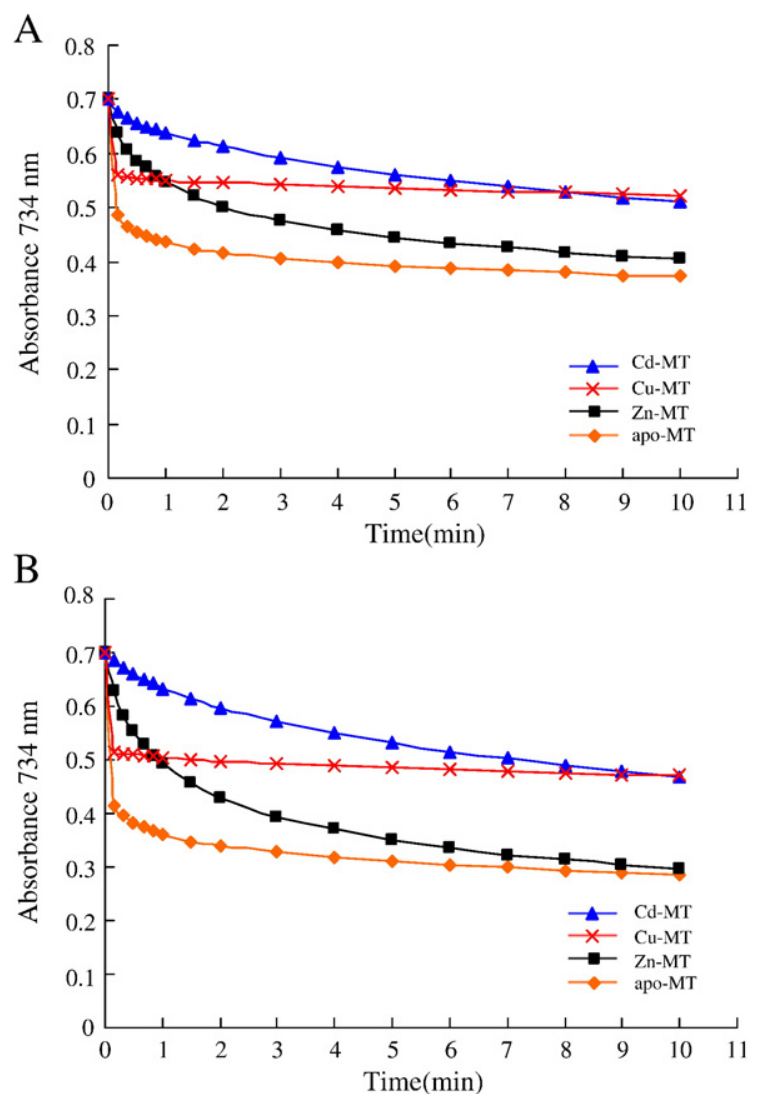

Fig. 6. Determination of free radical-scavenging activity using ABTS. The absorbance of ABTS. ${ }^{+}$was adjusted to an $\mathrm{OD}_{734}$ of 0.7 , then $3 \mu \mathrm{M}$ of apo-MT or metal ion-titrated MT was added. The decrease in absorption measured over time reflects the free radicalscavenging activity. (A) P. elongata MT-2; (B) M. posthuma MT-2. Means of three replications were displayed for absorbance measurements at each recorded time point. 
organisms (Park et al., 2007). However, the 4-fold lower rate consistently found during the steady phase of the DTNB assay indicates that M. posthuma MT-2 has a higher affinity for Cd than does $P$. elongata MT-2. The effect of the bioaccumulation of various heavy metals by different earthworm MT-2s has not been determined. A recent study reported species-specific patterns of heavy-metal bioaccumulation in earthworms (Kamitani and Kaneko, 2007). Our results provide evidence for a difference in metal-binding capabilities of earthworm MT-2s that may cause a difference in tolerance to heavy metals.

MTs play a role not only in heavy-metal storage, but also in genoprotection by minimizing free radical levels (Min et al., 1999; Min, 2007). Overproduction of MT has been shown to provide resistance to several forms of oxidative injury to cells (Lazo et al., 1998). Metalbound MTs purified from fish liver have been reported to be potent antioxidants against peroxidation and cytotoxicity due to free radicals (Atif et al., 2006). Moreover, MTs can act as a reservoir for zinc, one of the most abundant metals in organisms. However, free radicals can cause $\mathrm{Zn}$ release after oxidation of $\mathrm{Zn}-\mathrm{MT}$. We herein showed that metal-bound earthworm MT-2 was not as potent a free radical scavenger as reduced apo-MT, which caused a dramatic decolorization in the ABTS assay. The kinetics for Cu-MT showed an immediate reduction at the onset of the reaction, then a plateau. In contrast, Cd-MT and Zn-MT did not result in a marked decrease in absorbance, with Cd-MT giving a slower absorbance decrease than Zn-MT. Previous studies showed that recombinant MT-2 from $L$. rubellus coordinates seven Cd ions (Ngu et al., 2006), the molar ratio used in this study, and that MT is able to coordinate more $\mathrm{Cu}^{2+}$ than $\mathrm{Zn}^{2+}$ and $\mathrm{Cd}^{2+}$ (Nielson and Winge, 1984). Thus, in Zn-MT and Cd-MT, no free cysteines are expected to be present to react with ABTS, as all cysteines are assumed to form $\mathrm{Zn}$ - and Cd-thiolate structures; while, in $\mathrm{Cu}-\mathrm{MT}$, some free cysteine residues are still present and interact with ABTS. This may explain the dramatic absorbance decrease with $\mathrm{Cu}-\mathrm{MT}$ during the initial stage of the ABTS reaction, whereas the steady phase with $\mathrm{Cu}-\mathrm{MT}$ results from cysteines participating in tight copper coordination. Free radical scavenging depends on the number of accessible sulfhydryl groups in MT-2. The tight sequestration of metal ions indicates that the sulfhydryl groups of MT-2 are engaged in metal binding and are not available to eradicate free radicals.

\section{Conclusions}

We obtained the sequences of MT-2 from two species of Megascoleidae earthworms and describe how MT-2s function as effective biomarkers to evaluate heavy-metal pollution of soil. The complete amino acid sequences show high homology with previously published MT-2 sequences of lumbricid earthworms, but the conserved TQCCG sequence in lumbricid earthworms is replaced with TKCCG in megascolecid earthworms. The phylogenetic relationship of earthworms was analyzed using the reported MT-2 sequences and showed that $M$. posthuma and $P$. elongata are closely related species and clearly distinct from lumbricid earthworms. The recombinant proteins of MT-2 were produced and purified to characterize their biochemical properties, showing that their metal-binding capabilities are in the order of $\mathrm{Cu}^{2+}>$ $\mathrm{Cd}^{2+}>\mathrm{Zn}^{2+}$. However, earthworm MT-2s exhibit distinct kinetics of free radical scavenging that depend on the accessibility of sulfhydryl groups and the molar ratio of metals to MT-2.

\section{Acknowledgements}

We want to thank Prof. Michael Yudkin (Oxford University, Oxford, UK) for helpful discussion and Dr. Daniel Chamberlin for critically reading this manuscript. We are grateful to $\mathrm{H}$. J. Chen for technical assistance. This work was supported by a grant from the National Science Council of Taiwan to S.H.L. and C.C.C.

\section{References}

Amiard, J.C., Amiard-Triquet, C., Barka, S., Pellerin, J., Rainbow, P.S., 2006. Metallothioneins in aquatic invertebrates: their role in metal detoxification and their use as biomarkers. Aquat. Toxicol. 76, 160-202.

Atif, F., Kaur, M., Yousuf, S., Raisuddin, S., 2006. In vitro free radical scavenging activity of hepatic metallothionein induced in an Indian freshwater fish, Channa punctata Bloch. Chem. Biol. Interact. 162, 172-180.

Chen, W.Y., John, J.A., Lin, C.H., Lin, H.F., Wu, S.C., Lin, C.H., Chang, C.Y., 2004. Expression of metallothionein gene during embryonic and early larval development in zebrafish. Aquat. Toxicol. 69, 215-227.

Costello, L.C., Guan, Z., Franklin, R.B., Feng, P., 2004. Metallothionein can function as a chaperone for zinc uptake transport into prostate and liver mitochondria. J. Biol. Inorg. Chem. 98, 664-666.

Dai, J., Becquer, T., Rouiller, J.H., Reversat, G., Bernhard-Reversat, F., Nahmani, J., Lavelle, P., 2004. Heavy metal accumulation by two earthworm species and its relationship to total and DTPA-extractable metals in soils. Soil Biol. Biochem. 36, 91-98.

Dolderer, B., Echner, H., Beck, A., Hartmann, H.J., Weser, U., Luchinat, C., Bianco, C.D., 2007 Coordination of three and four $\mathrm{Cu}(\mathrm{I})$ to the alpha- and beta-domain of vertebrate $\mathrm{Zn}$ metallothionein-1, respectively, induces significant structural changes. FEBS Lett. 274 2349-2362.

Felsenstein, J., 1985. Confidence limits on phylogenies: an approach using the bootstrap Evolution 39, 783-791.

Gouet, P., Courcelle, E., Stuart, D.I., Metoz, F., 1999. ESPript: multiple sequence alignments in PostScript. Bioinformatics 15, 305-308.

Gruber, C., Stürzenbaum, S.R., Gehrig, P., Sack, R., Hunziker, P., Berger, B., Dallinger, R. 2000. Isolation and characterization of a self-sufficient one-domain protein (Cd)Metallothionein from Eisenia foetida. Eur. J. Biochem. 267, 573-582.

Hamer, D.H. 1986. Metallothionein. Annu. Rev. Biochem. 55, 913-951.

Jiang, L.-J., Vašák, M., Vallee, B.L., Maret, W., 2000. Zinc transfer potentials of the $\alpha$ - and $\beta$-clusters of metallothionein are affected by domain interactions in the whole molecule. Proc. Natl. Acad. Sci. U. S. A. 97, 2503-2508.

Kamitani, T., Kaneko, N., 2007. Species-specific heavy metal accumulation patterns of earthworms on a floodplain in Japan. Ecotoxicol. Environ. Saf. 66, 82-91.

Kim, J.H., Wang, S.Y., Kim, I.C., Ki, J.S., Raisuddin, S., Lee, J.S., Han, K.N., 2008. Cloning of a river pufferfish (Takifugu obscurus) metallothionein cDNA and study of its induction profile in cadmium-exposed fish. Chemosphere 71, 1251-1259.

Kimura, M., 1980. A simple method for estimating evolutionary rates of base substitutions through comparative studies of DNA sequences. J. Mol. Evol. 16, 111-120.

Knapen, D., Redeker, E.S., Inácioc, I., Coen, W.D., Verheyen, E., Blust, R., 2005. New metallothionein mRNAs in Gobio gobio reveal at least three gene duplication events in cyprinid metallothionein evolution. Comp. Biochem. Physiol. C Toxicol. Pharmacol. 140, 347-355.

Kumar, S., Nei, M., Dudley, J., Tamura, K., 2007. MEGA: Molecular Evolutionary Genetics Analysis software for microcomputers. Bioinformatics 10, 189-191.

Lazo, J.S., Kuo, S.-M., Woo, E.S., Pitt, B.R., 1998. The protein thiol metallothionein as an antioxidant and protectant against antineoplastic drugs. Chem. Biol. Interact. 111-112, 255-262.

Lukkari, T., Haimi, J., 2005. Avoidance of $\mathrm{Cu}$ - and $\mathrm{Zn}$-contaminated soil by three ecologically different earthworm species. Ecotoxicol. Environ. Saf. 62, 35-41.

Lukkari, T., Taavitsainen, M., Soimasuo, M., Oikari, A., Haimi, J., 2004. Biomarker responses of the earthworm Aporrectodea tuberculata to copper and zinc exposure: differences between populations with and without earlier metal exposure. Environ. Pollut. 129, 377-386.

Min, K.-S., 2007. Physiological significance of metallothionein in oxidative stress. Yakugaku Zasshi 127, 695-702.

Min, K.-S., Nishida, K., Onosaka, S., 1999. Protective effect of metallothionein to ras DNA damage induced by hydrogen peroxide and ferric ion-nitrilotriacetic acid. Nature 122 $137-152$.

Morgan, A.J., Stürzenbaum, S.R., Winters, C., Grime, G.W., Aziz, N.A., Kille, P., 2004 Differential metallothionein expression in earthworm (Lumbricus rubellus) tissues. Ecotoxicol. Environ. Saf. 57, 11-19.

Morgan, J.E., Morgan, A.J., 1998. The distribution and intracellular compartmentation of metals in the endogeic earthworm Aporrectodea caliginosa sampled from an unpolluted and a metal-contaminated site. Environ. Pollut. 99, 167-175.

Ngu, T.T., Stürzenbaum, S.R., Stillman, M.J., 2006. Cadmium binding studies to the earthworm Lumbricus rubellus metallothionein by electrospray mass spectrometry and circular dichroism spectroscopy. Biochem. Biophys. Res. Commun. 351, 229-233.

Nielson, K.B., Winge, D.R., 1984. Preferential binding of copper to the $\beta$ domain of metallothionein. J. Biol. Chem. 259, 1941-1946.

Park, H., Ahn, I.-Y., Choi, H.J., Pyo, S.H., Lee, H.E., 2007. Cloning, expression and characterization of metallothionein from the Antarctic clam Laternula elliptica. Protein Expr. Purif. 52, 82-88.

Piearce, T.G., Langdon, C.J., Meharg, A.A., Semplea, K.T., 2002. Yellow earthworms: distinctive pigmentation associated with arsenic- and copper-tolerance in Lumbricus rubellus. Soil Biol. Biochem. 34, 1833-1838.

Reinecke, A.J., Reinecke, S.A., Maboeta, M.S., 2001. Cocoon production and viability as endpoints in toxicity testing of heavy metals with three earthworm species. Pedobiologia 45, 61-68.

Reinecke, F., Levanets, O., Olivier, Y., Louw, R., Semete, B., Grobler, A., Hidalgo, J., Smeitink, J., Olckers, A., Van der Westhuizen, F.H., 2006. Metallothionein isoform 2A expression is inducible and protects against ROS-mediated cell death in rotenonetreated HeLa cells. Biochem J. 395, 405-415.

Saitou, N., Nei, M., 1987. The neighbor-joining method: a new method for reconstructing phylogenetic trees. Mol. Biol. Evol. 4, 406-425. 
Santovito, G., Formigari, A., Boldrin, F., Piccinni, E., 2007. Molecular and functional evolution of Tetrahymena metallothioneins: new insights into the gene family of Tetrahymena thermophila. Comp. Biochem. Physiol. C Toxicol. Pharmacol. 144, 391-397.

Sheppard, S.C., Evenden, W.G., Cornwell, T.C., 1997. Depuration and uptake kinetics of I $\mathrm{Cs}, \mathrm{Mn}, \mathrm{Zn}$ and $\mathrm{Cd}$ by the earthworm (Lumbricus terrestris) in radiotracer-spiked litter. Environ. Toxicol. Chem. 16, 2106-2112.

Stürzenbaum, S.R., Kille, P., Morgan, A.J., 1998. Heavy metal-induced molecular responses in the earthworm, Lumbricus rubellus genetic fingerprinting by directed differential display. Appl. Soil Ecol. 9, 495-500.

Stürzenbaum, S.R., Winters, C., Galay, M., Morgan, A.J., Kille, P., 2001. Metal ion trafficking in earthworms. J. Biochem. Chem. 276, 34013-34018.
Svendsen, C., Weeks, J.M., 1996. Relevance and applicability of a simple earthworm biomarker of copper exposure: I. links to ecological effects in a laboratory study with Eisenia andrei. Ecotoxicol. Environ. Saf. 36, 72-79.

Toriumi, S., Saito, T., Hosokawa, T., Takahashi, Y., Numata, T., Kurasaki, M., 2005. Metal binding ability of metallothionein-3 expressed in Escherichia coli. Basic Clin. Pharmacol. Toxicol. 96, 295-301.

Valls, M., Bofill, R., Gonzalez-Duarte, R., Gonzalez-Duarte, P., Capdevila, M., Atrian, S., 2001. A new insight into metallothionein (MT) classification and evolution. J. Biol. Chem. 276, 32835-32843.

Verstrepen, K.J., Jansen, A., Lewitter, F., Fink, G.R., 2005. Intragenic tandem repeats generate functional variability. Nat. Genet. 37, 986-990. 